$64: 204$

＼cjkstart症例報告 $>$

長期間経過を追跡し得た原発性胆汁性肝硬変症の一症例

\begin{tabular}{|c|c|c|c|c|c|c|}
\hline 多羅尾和郎 & 船山 & 道敏 & 杉政 & 龍夫 & 遠藤 & 修 \\
\hline 松崎 & 戸田 & 有亮 & 條山 & 隆 & 池内 & 孝夫 \\
\hline 信彦 & 大塚 & 明子 & 福島 & 孝吉* & 永岡 & 貞男** \\
\hline
\end{tabular}

要 旨：最近本邦においても原発性胆汁性肝硬変症（primary biliary cirrhosis, 以下 PBC と略) の症例が散見されるようになったが，長期間経過を追跡し得た症例の報告は今だ少ない，我々は 最近 7 年以上の長期間にわたる全経過を追跡し得た典型的な PBC の一例を経験し，更に死後剖 検する機会を得たので若干の考察を加えて報告する。

症例は42歳の女性で初発症状は癌痒感で慢性の閉塞性黄疸と全身の色素沈着があり, 高アルカ リフォスファターゼ血症, 高コレステロール血症がみられたが, 逆行性膆胆管造影及び剖検では 肝外胆道閉塞は否定され，2回の肝生検及び剖検で小葉間胆管の破壊消失が目立ち，抗ミトュン ドリフ抗体も陽性で肝脾の腫大, 病的骨折もあり, 典型的な PBCであった。

索引用語：原発性胆汁性肝硬変症

はじめに

原発性胆汁性肝硬变症は，従来 xanthomatous biliary cirrhosis (Thannhauser \& Magendantz"), 1938), cholangiolitic hepatitis (Watson \& Hoffbauer, ${ }^{23}, 1946$ ), pericholangiolitic biliary cirrhosis (MacMahon', 1955), chronic intrahepatic obstructive jaundice (Sherlock ${ }^{5}$, 1959), chronic non-suppurative destructive chlangitis (Rubin, Sohaffner \& Popper ${ }^{6}$ ，1965) 等の名称でも記 載されて拁り，臨床的には徐々に始まって長期間持続す る慢性の閉塞性黄㡺と, 皮府强廉感, 黄色腫, 高コレス テロール血症, 血清フルカリフォスファターせ活性値の 著明な上昇, 肝脾腫等の症状によって特徴つけられ, 閉 塞性黄疾の应状を呈しながら, 肝外胆道系に閉塞機転が 存在しないものである，病理組縺学的には，胆汁性肝硬 变が完成した末期においては, 他の肝硬変症との区別が 一般に極的困難となるが，早期に打ける病变は，小葉 間胆管 (interlobular bile duct) を中心とした顕微鏡的レ ベルでの中等大の胆管に括ける非可这的破壊性病変と， その周囲の円形細胞浸潤を伴ら肉芽性病变の出現が本疾

$*$ 横浜市立大学第一内科

*** 横浜市立大学第一病理

〈受付日50年 9 月 29 日 $>$
患を特徽づけるるのであり，これが本症の疾患概念の独 立性を認める要因となっている。

歴史的には1875年 Hanot $^{7}$ が「慢性黄㾝を伴ら肥大 性肝硬変症」を記載し，更に1893年 Kiener ${ }^{\mathrm{B})}$ がこれに 「Hanot 型肥大性肝硬変症」なる名称を提唱したが，今 日一般にこれが本疾患の最初の記載と理解されている. 本疾患が従来種々の名称で記載されてきた主な理由の 一つは, 肝の形態的病变が病期によって著しく異なるこ と, 及び肝内性閉塞性黄㡺の発生機序に不明な点が多く あったことにあると考えられる.1949年，Ahrens" が初 めて“primary biliary cirrhosis" (以下PBC々記す) なる 名称を提陧して以来，この名称汇多少の批判はあるが， 今日これが広く使用されるよらになった。

一方, 病因論的に绀近年の免疫学の発達に伴って, 破 壊された胆管周囲に括ける IgM 沈着の証明, 更に抗: トコンドリア抗体出現等の免度学的特異性に関する新知 見によって，詳細なメカニズムは不明であるが，自己免 疫的機序の関与が主役を演していると考えられている点 で興味深い。

本疾患は以前は本邦では比較的稀な疾患とされていた が，最近では報告が散見される様になり，我々の調へた 範囲では今迄に約50例前後の報告がある。我々も近年 PBC の 1 症例を約 7 年間の全程過にわたり，释過を追 
Table 1 Laboratory analyses in the Keiyū Hospital

\begin{tabular}{|c|c|c|c|c|c|c|c|c|c|c|}
\hline & $\begin{array}{c}1967 \\
12 / 19\end{array}$ & $\begin{array}{c}1968 \\
1 / 10\end{array}$ & $1 / 24$ & $2 / 14$ & $2 / 21$ & $3 / 6$ & $4 / 10$ & $5 / 1$ & $6 / 5$ & $6 / 12$ \\
\hline $\mathbf{T} \cdot \mathbf{P}$ & 7.9 & & & & & & & & & \\
\hline$A / G$ & 0.75 & & & & & & & & & \\
\hline$r-\mathbf{G} \ell$ & 23 & & & & & & & & & \\
\hline $\begin{array}{c}\operatorname{GOT} \\
\left(\operatorname{Karm}_{\operatorname{man}}\right)\end{array}$ & 60 & 240 & 210 & 185 & & 32 & 135 & 95 & 180 & \\
\hline$\left(\begin{array}{c}G P T \\
\left(\operatorname{Rarmon}^{\prime}\right)\end{array}\right.$ & 51 & 235 & 205 & 215 & & 63 & 179 & 26 & 270 & \\
\hline T T T & 4.5 & & & & & & & & & \\
\hline Z T T & 8.5 & & & & & & & & & \\
\hline 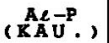 & 37.5 & 100.0 & 71.5 & 74.5 & 95.0 & 47.7 & 115.0 & 74.5 & 85.0 & 97.0 \\
\hline$T-B i l$ & 3.6 & 2.9 & 1.1 & 1.1 & & 3.2 & & 2.3 & 1.0 & \\
\hline T-Cho. & 462 & 432 & 452 & 466 & 622 & 596 & 538 & 420 & 445 & 477 \\
\hline
\end{tabular}

Therapy

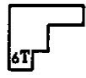

Rinderon

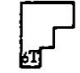

Kenacor:

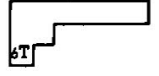

Prodonine
跡し得たので若干の文献的考察を加兄報告する。

应 例：42歳(48年 9 月当科入院時),主婦

主 訴: 黄庭, 全身搔㾕感

家族歴：特記すべきことなし

既往歴：33歳, 妊㖘 3 カ月で切迫流産, 34歳, 妊娠 8 カ月で胎児死亡.

現病歴：昭和 42 年 5 月（当時 36 歳),娃娠 6 力月の時, 薬物服用等の誘因むなく, 突然全身掹痒感が出現し, 次 第に增強した．11月警友病院で逆子で片足位分婏の為， 帝王切開にて胎児を婏出したが，その際輸血を $600 \mathrm{ml}$ 受けた．出産後も提㾕感は全く変らず, 皮虐科にて治療 を受けていた，42年12月に初めて黄疸が出現し，同病院 で肝機能を検查したところ，著明な異常を指摘され入院 した. 警友病院入院中の肝機能検查結果を Table 1 k示 すが，これ等の中，目立つ点は，アルカリフォスファタ 一ゼと総コレステロールの著明な上昇で，アルカリフォ スファターセは最高 115K.A.U. Kも達し, 又総コレス テロールも最高 $622 \mathrm{mg} / \mathrm{d} l$ にも上昇した. しかし、こ れ等の高値にも拘らず, 総ビリルビンの上昇は軽度で最 高 3.6mg/dl にとどまっていた。 その他では, transaminase 值が 200単位前後の軽度上昇を示していた。

昭和42年12月の警友病院入院直後に行なわれた肝生榆 (needle biopsy) の結果, 病理組織学的に慢性肝炎 と 訩断された．当時の組織像は Fig. 1 及び2の如くで, Glisson 葽内の小葉間胆管及び細胞管 (bile ductule) K 可成りの破垻像があり，周囲に中等度の小円形細胞浸潤
を認めた．浸潤緗胞はリンバ球が大部分を占め，形質稩 胞の出現は極めて少ない，Glisson 鞘内の胆管及び 毛細 胆管 (bile canaliculus, Gallen-kapillaren) k胆栓の出現 は認められなかった．又， siurrsoid 内には所々星細胞の 結節性增殖が認められた。所謂 Councilman body の出 現は認め得なかった。

以後、ステロイドホルモンによる治療を受けたが何等 の効果なく，全身の色素沈着む著明に増強した。

更に昭和43年 3 月，第 2 回目の肝生検が行なわれ，細 胆管炎性肝炎 (cholangiolitic hepatitis) の確診が下され

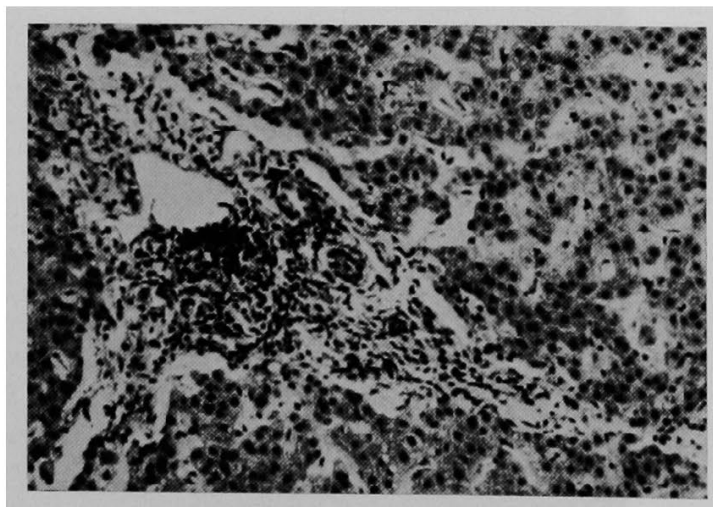

Fis. 1 Section of the liver from the first needle biopsy. There is moderate round cell infiltration, principally lymphocytic, in the portal area. Interlobular bile ducts are severly destroyed. Hematoxylin and eosin stain, $\times 180$. 


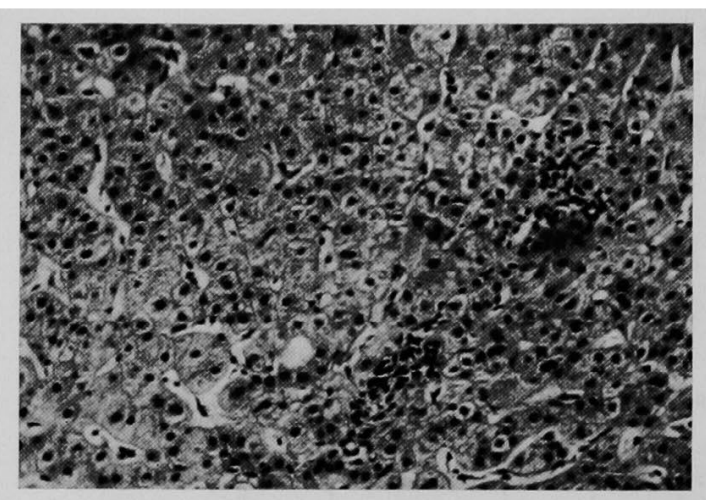

Fig. 2 Same section as in Figure 1, showing focal proliferation of intralobular sinusoidal cells. Hematoxylin and eosin stain, $\times 180$.

た. その際の組織像は Fig. 3 の如くで, 基本的には前回 の所見と変わるところはないが, 大部分の小葉間胆管が 破壊されており, Glisson 鞘は多少桩大し, 小円形細胞浸 潤が僅かに増強の傾向が認められた，その後も諸症状に

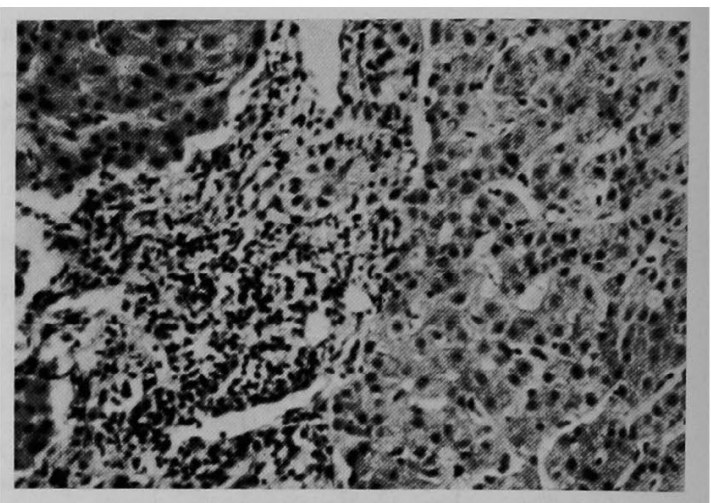

Fig. 3 Section of the liver from the second needle biopsy. A portal area showing sever damage of interlobular bile ducts surrounded by marked round cell infiltration. Hematoxylin and eosin stain, $\times 180$.

著変が無い為, 同年 6 月中旬, 警友病院を退院し, 通院 にて様子をみていたが，6月下旬になり，頙椎の病的骨

Table 2 Laboratory analyses on admissin to the Yokohama City University Hospital

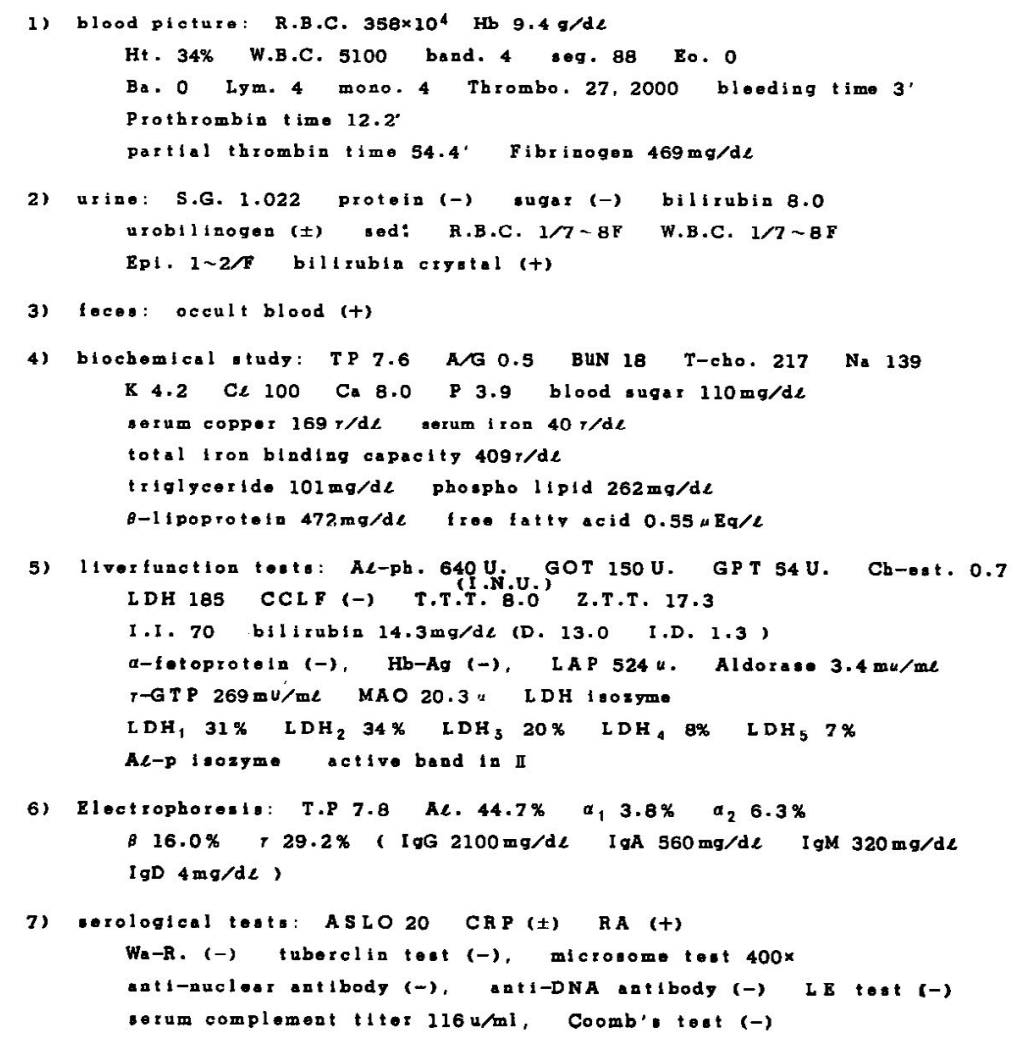




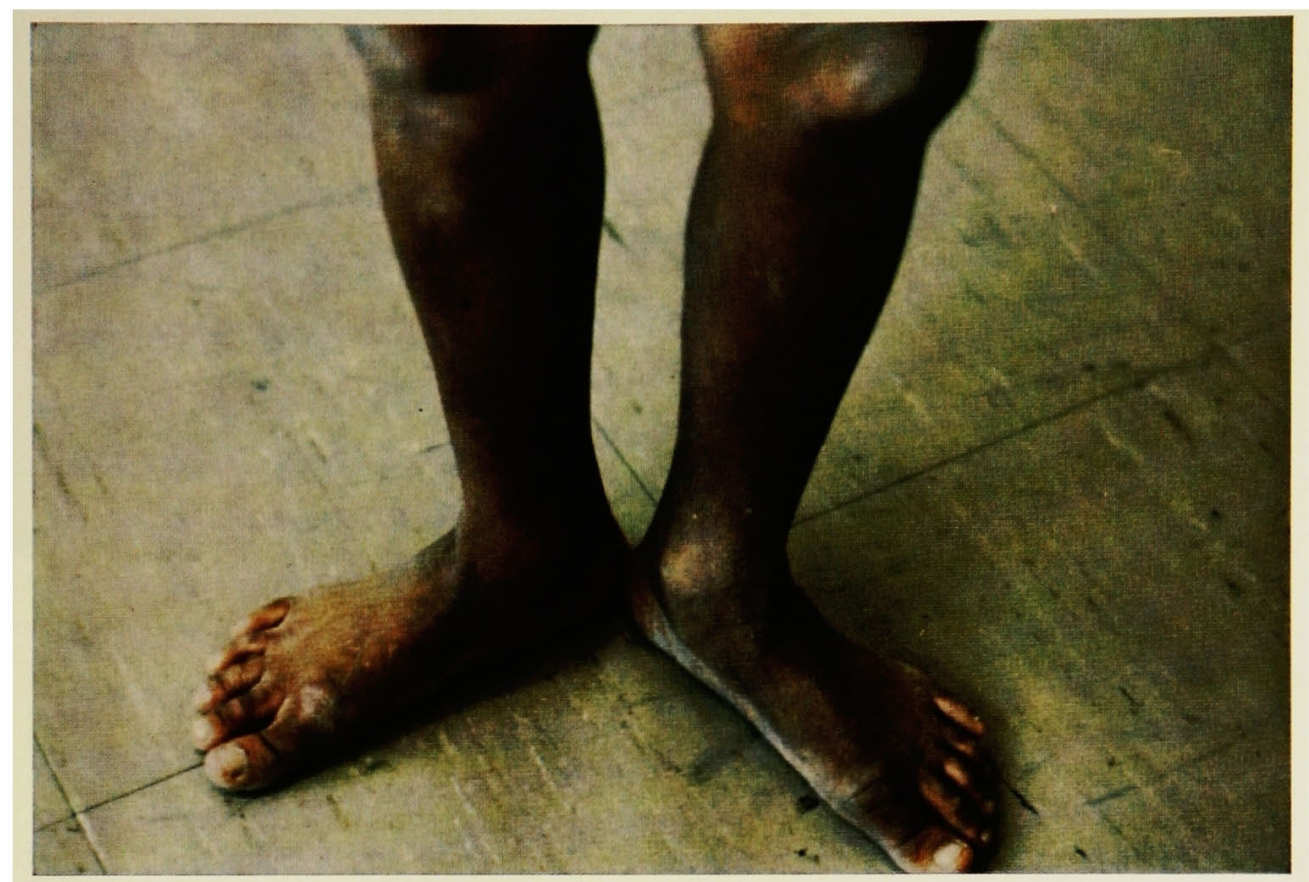

Fig. 4 Marked hyperpigmentation of the legs.

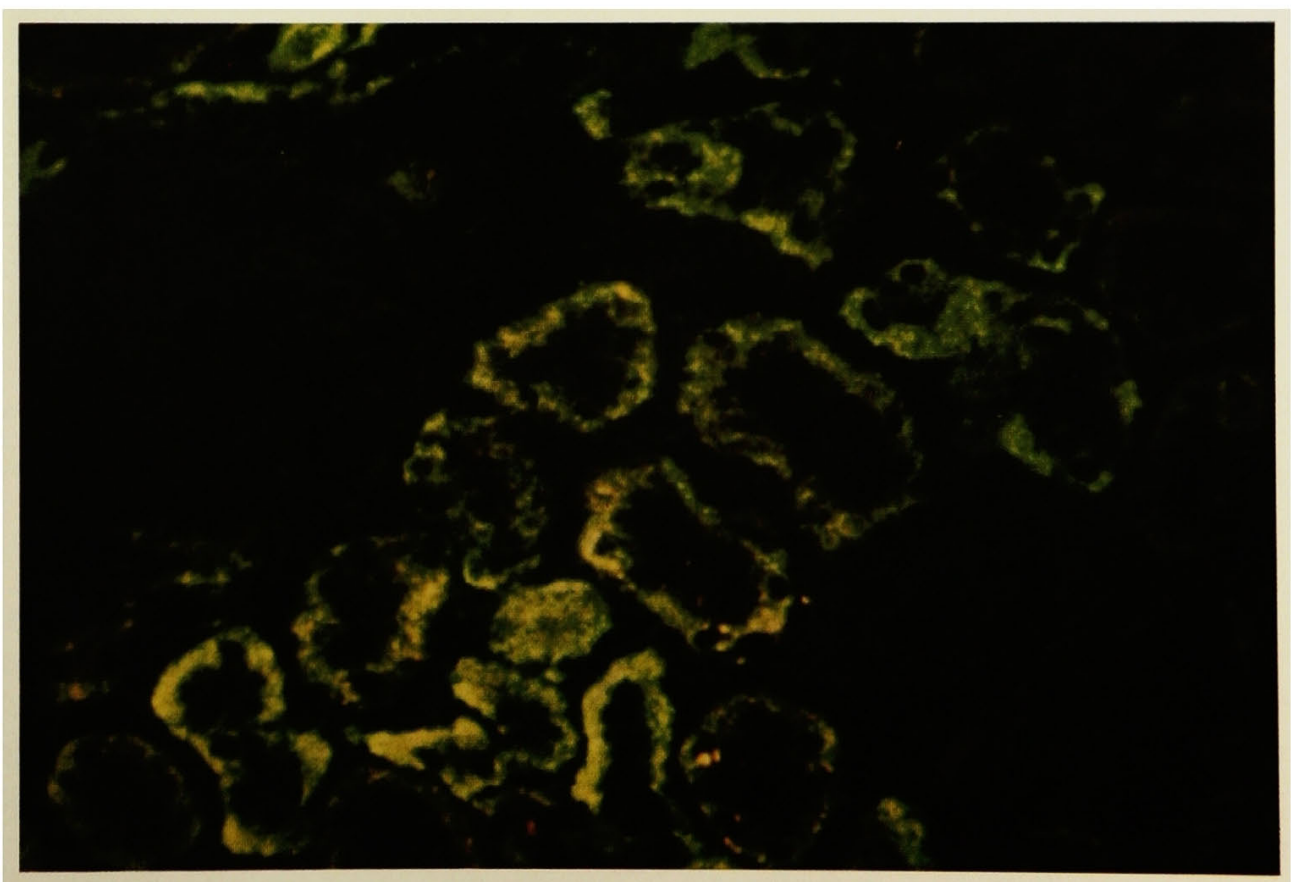

Fig. 5 The mitochondrial immunofluorescent test showing granular cytoplasmic staining in unfixed tissue sektion of rat kidney. $\times 400$ 
$68: 208$

折を生じた。この後も軽度黄疸は続いたが，撞㾕感は一 時軽快した。しかし，48年 5 月になり，搔痒感，黄疸が 増強し, 更に全身倦宫感も加わり，同年 9 月 4 日，当科 ヘ入院した。

入院時現症 :

体格小，栄養中等度，意識清明，脈指 $96 /$ 分，整，血 圧 $110 / 70$, 眼球結膜に黄㾞, 腿䀫結膜に貧血あり, 頚 部をはじめ表在性リンパ筋の腫脹なし、胸部では打聴診 上異常なく，くも状血管腫む認めず．腹部では，肝を 4 横指触知し, 表面平滑, 辺縁鈍, 硬度は弾性硬であり, 又, 脾は 3 横指触知した. 腹壁静脈怒張なく, 腹水は証 明されなかった。下眼浮腫なし、更に，全身の皮屑には 黄疾，色素沈着が著明で，特に Fig. 4 の如く，四肢伸側 の皮店は色素沈着が強く，黒ずんで拈り，乾燥し，硬く ざらざらした感じが著明であった。

\section{入院時諸検查成績 :}

Table 2 の如く, 血沈 1 時間値 105 ミリと著明に九進 し，尿中ビりルビンは強陽性であった．末梢血液所見で は, 赤血球数 358 万, $\mathrm{Hb} 9.4 \mathrm{~g} / \mathrm{d} l$, F.I. 0.82 , と軽度の 貧血が認められ，又，白血球数 5,100 , 血液像では好中 球増多を示した。

生化学検查では Table 2 の如く, transaminase の軽 度上昇及び，Al-ph. 640国際単位と著明な上昇を認め,

又, 総ビリルピン值も $14.3 \mathrm{mg} / \mathrm{d} l$ （直接ビリルビン值 $13.0 \mathrm{mg} / \mathrm{d} l$ ) と著增していた. 一方, 膠原反応もチモール 8.0 , 硫酸西鉛 17.3 と異常高值を示し, 血清蛋白分画で む $\gamma$-globulin $29.2 \%$ 著増していたか，総コレステロ 一ル値は $217 \mathrm{mg} / \mathrm{d} l$ と正常値に復していた。

免疫学的検查では RA 陽性, IgA, IgM が軽度に増加 していたが，抗核抗体，LE 細胞は陰性であった。 又, AU 抗原 (HB 抗原) b陰性であった. 抗ミトコンドリ 了抗体は, 抗胃壁細胞抗体で 256倍, 抗尿細管上皮細胞 抗体で128倍と陽性を示した. Fig. 5 は抗尿細管上皮細胞 抗体を示す).

一方, 上部消化管 $\mathbf{X}$ 線像では異常は無かった，肝シン チグラムでは, Fig.6の如く, 肝硬変のパターンを示し た.

腹腔鏡検查では，肝は緑褐色の cholestasis の所見を示 し，右葉はやや萎縮し、結節形成が著明であったか，左 葉は著明に肥大し, 表面には凹凸のみで結節形成は認め られなかった。

逆行性胆管造影では，Fig. 7 の如く，肝外胆管及び肝 内主要胆管の閉塞像はなかった。

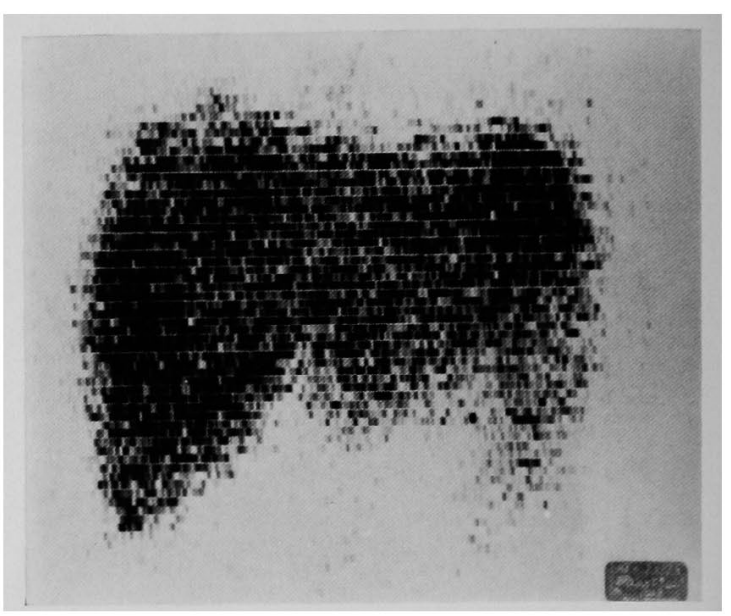

Fig. 6 Scintiscan using ${ }^{198} \mathrm{Au}$ on the 17 th of Sept. in 1973, showing large liver and large spleen.

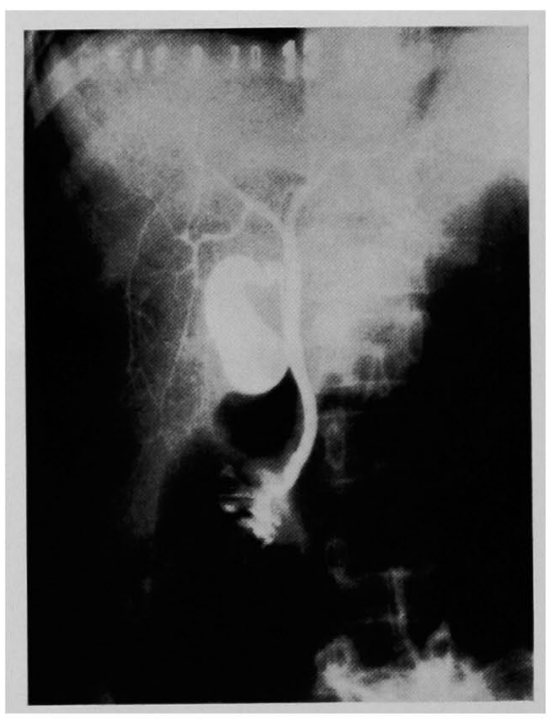

Fig. 7 Endoscopic pancreatico-cholangiography, showing no obstruction in extrahepatic bile ducts.

\section{入院後の経過：(Fig. 8 参照)}

プレドニンを94日間, 総計2655mg 役与したが, GOT, GPT はそれぞれ80〜290，30〜340国祭単位を変動し， Al-ph は 400 940 国際単位, 総ビリルビンは23.0mg/ $\mathrm{d} l$ と更に上昇した (Table 3，4参照). 10月5 日，右 第 9 助骨の病的骨折が出現, この時の血清 $\mathrm{Ca}$ 值は 8.0 $\mathrm{mg} / \mathrm{d} l$ と低下していた．10月下旬より腹水が生じ，ラシ ックス等の利尿剂投与にも拘らず, 以後項固に持続し た. 又，49年 1 月18日に行った第 2 回目の肝シンチグラ ムでは, Fig. 9の如く, 肝は入院時の第 1 回目に比し 
Table 3 The course of the patient on laboratory examination during admission to the Yokohama

City University Hospital ( I )

\begin{tabular}{|c|c|c|c|c|c|c|c|c|c|c|c|c|c|}
\hline & $\begin{array}{l}1973 \\
\text { Sept. }\end{array}$ & & Oct. & & Nov. & & Dec. & & $\begin{array}{l}1974 \\
\text { Jan. }\end{array}$ & & $F \bullet b$. & & Ma 7. \\
\hline $\mathbf{T} \cdot \mathbf{P}$ & 7.8 & 2.0 & 5.5 & 6.1 & 5.6 & 6.0 & 6.2 & & 6.7 & 6.4 & 6.2 & & 3.9 \\
\hline$A / G$ & 0.5 & 0.5 & 0.8 & 1.1 & 0.8 & 0.9 & 0.6 & & 0.7 & 0.6 & & & 0.5 \\
\hline$A 2$ & $44.7 \%$ & 46.3 & 49.5 & & & & & & 48.1 & & 50.4 & & \\
\hline$a_{1}$ & 3.8 & 3.9 & 4.3 & & & & & & $3 \cdot 7$ & & 3.7 & & \\
\hline$\alpha_{2} \alpha_{2}$ & 6.3 & 4.9 & 10.2 & & & & & & 8.0 & & 10.6 & & \\
\hline A & 16.0 & $17 \cdot 7$ & 11.5 & & & & & & 10.3 & & 13.8 & & \\
\hline Ir & 29.2 & 26.9 & $24 \cdot 5$ & & & & & & 21.3 & & 21.2 & & \\
\hline $\begin{array}{l}\text { T-cho. } \\
\text { (mg/de) }\end{array}$ & 217 & & & 210 & 207 & & & 243 & 242 & 172 & & 127 & 130 \\
\hline $\begin{array}{l}\mathrm{Al}-\mathrm{ph} \\
(\mathrm{I} \cdot \mathrm{N} \cdot \mathrm{U})\end{array}$ & 648 & 552 & 532 & 815 & 810 & 940 & 780 & 715 & 850 & 740 & 535 & & 607 \\
\hline $\begin{array}{l}\text { GOT } \\
\text { (I.N.U) }\end{array}$ & 150 & 131 & 225 & 250 & 216 & 198 & 125 & 119 & 268 & 133 & & 86 & 86 \\
\hline $\begin{array}{l}\text { GPT } \\
\text { (I.N.U) }\end{array}$ & 54 & 48 & 240 & 308 & 213 & 143 & 72 & 49 & 48 & 38 & & 24 & 29 \\
\hline L D H & 185 & 215 & 230 & 259 & 280 & & & 282 & 279 & 379 & 378 & & 450 \\
\hline Cho. ent & 0.7 & 0.8 & 0.6 & & 0.6 & & & & 0.7 & & & & 0.7 \\
\hline Z T T & 17.3 & 14.4 & 5.0 & 3.7 & 3.2 & 3.1 & 2.4 & 2.6 & 2.8 & 3.6 & & & 2.2 \\
\hline $\mathrm{TTT}$ & 8.0 & 8.4 & 2.2 & 3.7 & 3.1 & 3.1 & 4.6 & 4.4 & 3.4 & 3.7 & & & $2 \cdot 3$ \\
\hline 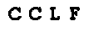 & $(-)$ & $(-)$ & $(-)$ & $(-)$ & & & & & $(-)$ & $(-)$ & & & $(-)$ \\
\hline$M \quad G$ & 70 & 100 & 80 & 100 & 70 & & 100 & 200 & 200 & 150 & 300 & 150 & 120 \\
\hline T-Bil & 14.3 & 15.9 & 8.9 & 11.3 & 8.9 & 16.7 & 12.3 & 16.1 & 20.5 & & & 16.4 & 13.1 \\
\hline$i^{\mathrm{D}}$ & 13 & 11 & 6.7 & 9.4 & 8.0 & 11.0 & 11.3 & 10.9 & 16.5 & & & 11.9 & 12.1 \\
\hline$V_{I}$ & 1.3 & 2.9 & 2.2 & 1.9 & 0.9 & 5.7 & 1.0 & 5.2 & 4.0 & & & 4.5 & 3.0 \\
\hline
\end{tabular}

Table 4 The course of the patient on laboratory examinatin during admission to the Yokohama City Univ. Hospital ( II)

\begin{tabular}{|c|c|c|c|c|c|c|c|c|c|c|c|c|c|c|}
\hline \multirow{3}{*}{$\begin{array}{c}\text { BUN } \\
\text { Croatin }\end{array}$} & \multicolumn{2}{|c|}{$\begin{array}{l}1973 \\
\text { Sept. }\end{array}$} & \multicolumn{2}{|l|}{ Oet. } & \multicolumn{2}{|l|}{ Nov. } & \multicolumn{2}{|c|}{ Dec. } & \multicolumn{2}{|l|}{$\begin{array}{l}1974 \\
\mathrm{Jan} .\end{array}$} & \multicolumn{2}{|l|}{ Fob. } & \multicolumn{2}{|c|}{ Max. } \\
\hline & 18 & 9 & & & & & & & 12 & 6.0 & 24 & & & 121 \\
\hline & & & & & & & & & & 2.4 & & & & \\
\hline $\mathbf{N}$ & 136 & 137 & 143 & 140 & 141 & 142 & 140 & 142 & 135 & 141 & 138 & 139 & 139 & 136 \\
\hline $\mathbf{x}$ & 3.9 & 4.1 & 4.1 & 3.4 & 4.3 & 4.1 & 3.8 & 3.3 & 3.9 & 4.3 & 3.2 & 3.4 & 3.5 & 1.7 \\
\hline C 2 & 100 & 204 & 102 & 104 & 103 & 101 & & 100 & 97 & 104 & & 96 & 92 & 86 \\
\hline $\mathbf{P}$ & & & & 3.9 & 3.8 & 4.2 & $4 \cdot 3$ & & & & & & & \\
\hline C. & & & & 8.0 & 9.0 & 8.9 & 0.6 & & & & & & & \\
\hline B.s.R. & 105 & 105 & 40 & 18 & 60 & 83 & 38 & $\mathbf{5 5}$ & 60 & 55 & 35 & 59 & 51 & 30 \\
\hline$I_{2}$ & 120 & 126 & 83 & 42 & 93 & 110 & 80 & 105 & 100 & 107 & 80 & 102 & 59 & 55 \\
\hline $\mathbf{N H}_{3}$ & & & & & & & & & & & & & & $10 \mathrm{r} / \mathrm{d} \ell$ \\
\hline C R P & $( \pm)$ & & & & & & H) & & $( \pm)$ & & & & & \\
\hline RA & $(t)$ & & & & & & $-)$ & & $(-)$ & & & & & \\
\hline ASLO & 20 & & & & & & 20 & & 40 & & & & & \\
\hline
\end{tabular}



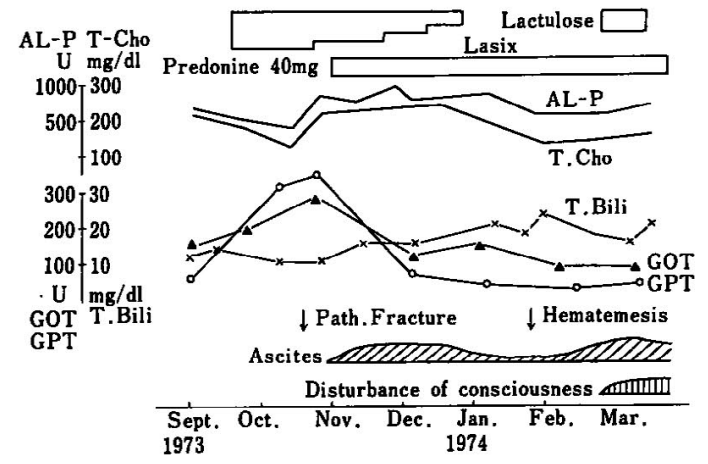

Fig. 8 Clinical course of the Patient

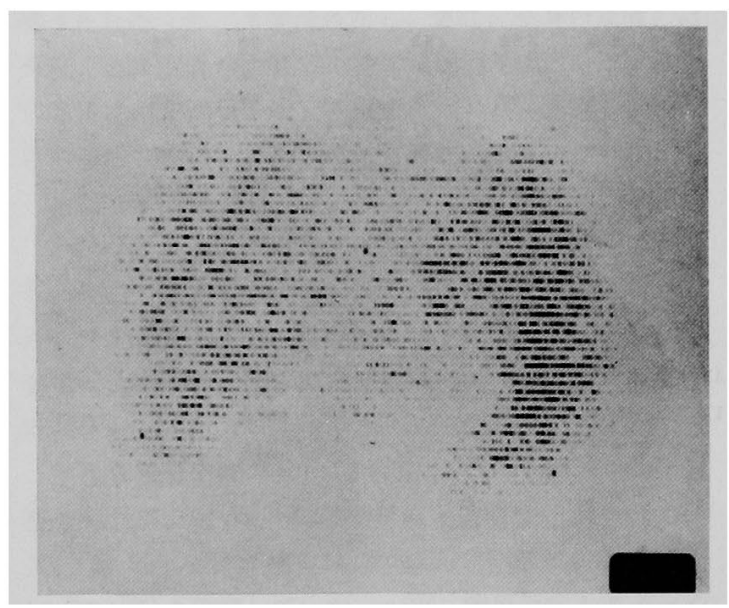

Fig. 9 Scintiscan using ${ }^{198}$ Au on the 18 th of Jan. in 1974, showing generalized decrease in hepatic uptake.

て，極度に菲薄化し脾影が増大していた，又，頑固な提 㳯に対してはコレスチラミン等を投与したが無効であっ た. 1 月20日夜食道静脈瘤上りの大量の吐血が起こり, Sengstaken-Blakemore tube にて止血したが，この頃よ り, 黄瘨, 色素沈着か更に增強した。 2 月25日より意識 は傾眠状熊となり，血中アンモ二ア值は $210 \gamma / \mathrm{d} l$ と上昇 した. その後, 血圧は徐々に下降し，3月21日, 入院後 191日にして全身衰弱で死亡した. 尚,テラマイシン等抗 生剤使用の為か全経過を通して著明な発熱は一度も無か った.

\section{剖検所見}

剖検診断（剖検番号 : A-1757, 死後31時間）

1. 原発性胆汁性肝硬变症 $(1440 \mathrm{~g})$

2. 色素沈着を伴ら著明な全身黄疸

3. 䀒外胆道系炕異常所見なし.
4. 慢性亏っ血性脾重 $(270 \mathrm{~g})$

5. 食道静脈瘤破綻後状態（破綻部比 2 倍小指頭大の 凝血附着を伴ら）

6. 黄色透明腹水 $1500 \mathrm{~m} l$

7. 胆汁性ネフローゼ

8. 第 5 頝椎, 右第 9 助骨の病的骨折を伴う稍々著明 な骨軟化症

9. 敗血症：

$$
\begin{aligned}
& \text { 1. 蜂窩織炎性結腸炎 } \\
& \text { 口. 粟粒大の多発性腎膿湟 } \\
& \text { 八. 散布性心筋内影微鏡的膿灌 } \\
& \text { 二, 両側副督の広沉な出血, 壊死 }
\end{aligned}
$$

10. 下腹部帝王切開術洎痕

以下, 剖検所見の大要を述べる.

外表所見 :

体格小（身長 $142 \mathrm{~cm}$ ), 栄養状態不良. 全身黄疸色著明 にして皮㲊は乾燥し，黒褐色調の著明な色素沈着を伴う． 浮腫, 腹壁静脈怒張, 出血傾向は認めない. 表在性リン パ節を触れず，口腔内にコーヒー様残椬を含む赤黑色の 血性吐物あり。

一般内詈所見：

腹腔開検 : 腹腔内に黄色透明腹水 $1500 \mathrm{~m} l$. 横隔膜はや や挙上し (左第 3 助骨上縁, 右第 4 助骨上緑に相当). 肝 右葉は右胁骨弓内にあり, 脾は左胁骨弓内にある.

胸䏶開検 : 胸膜㾤着なく, 胸膜腔は左 $40 \mathrm{ml}$, 右 $50 \mathrm{~m} l$ の黄色透明液を容れる.

肝内部に 1 個の大豆大に隀大したリンバ節を見る他は 胸腹部のリンパ節の腫大なし.

葴器別所見 :

1. 肝蔵：重量 $1440 \mathrm{~g}$. 高度に進行し, 完成された胆 汁性肝硬変症の像で, 硬度は著しく增加し, 被膜は軽度 に肥厚, 表面は少しく結節状を呈するす著しい凹凸はな い. 割面は暗緑褐色調を呈し，細かい網目状を呈する結 合織の増加が著明である．結合織に囲まれた肝小葉は注 ぼ均等に近く, 結節性肥大は認められない，肝内胆管の 扗張は全くない。

組織学的には Fig.10の如く，結合織の増加は著明なる る改築はあまり目立たず，残存せる肝小葉は多少の大小 不同はあるわのの，著しい差異はなく，個々の小葉は Glisson鞘を中心として増殖したと見做し得る結合織によ ってとり囲まれている．結合織は線維細胞乃至線維芽細 胞にゃや乏しく、膠原線維が主成分を占めている． septal bile duct を含ぬて太い胆管は一般によく保たれている 


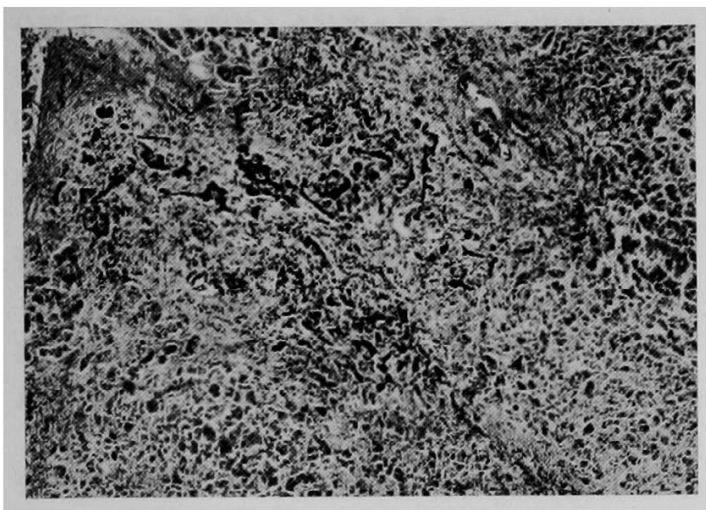

Fig. 10 Section of the liver from the autopsy material, showing advanced stage of primary biliary cirrhosis. Broad strand of fibrous tissue with proliferation of new bile ductules separates liver cell groups. Interlobular bile ducts are disappeared. Hematoxylin and eosin stain, $\times 64$

すのが多く，胆汁のうっ帯像はない，小策管胆管（但 し大型の）は一部に辛じて破埭を免がれているものがあ るが，一般に増生した結合織内には既存の小莱問胆管は 殆んど消失し，代って偽胆管の增生が到る所に著明に認 められる. 小葉内の毛細胆管の到る所に，又，小葉周辺 部に接近して見られる上記僣胆管内に胆栓形成が認めら れた。細胞浸潤は軽く，結合織の疁原化と共に可成り痏 痕化の進行を思わせたが，所々 lymphfolliculoid formationが散見された，浸潤細胞は専らリンパ球からなり， 形質細胞, 顆粒白血球の出現は認められないが,リンハ 滤胞様のリン八球集簇部ではごく少数の胆汁色素を会食 した組織球の混在が認められた。

2. 肝内部：胆重は収縮し, 中に少量の淡緑色透明で 粘稒な胆汁を容れている，肝管，総胆管に異常なく，組 織学的にも肝外胆道系の何れの部分にも炎症性病変は認 められない. 肝門部リンパ節は黄㡺色を伴って大豆大に 睡大するも，組織学的に胆汁色素沈着を伴う慢性洞カタ ルが主体で実質細胞は減少している．形質細胞は殆えど 認めない。

3. 脾臟：重量 $270 \mathrm{~g}$, 血液量少なく, 組織学的には 所罣“Fibroadenie” に相当する像である.

4. 照㖑：左 $150 \mathrm{~g}$, 右 $170 \mathrm{~g} て ゙$, 胆汁性ネフロービ の像の他に果粒大の小膿湯が多数散見された．腎孟粘膜 には炎症性病变を認めない。

5. 心臓：重量 $260 \mathrm{~g}$ ，肉眼的には著変を認め得ない が，䫒微鏡的に膿笠が散見された。
6. 副㥜：広沉な出血と皮質の壊死を認め，髄質静脈 の周囲に白血球浸潤が認められた。

7. 結腸は汪注全長にわたり，粘膜下組織に一致して 著明な浮腫と中等度の好中球のびまん性浸潤を認め, 蜂 窝織炎性結腸炎に一致する像であった。

8. 肺: 左 $300 \mathrm{~g}$, 右 $330 \mathrm{~g}$ で, 極めて軽度の浮腫の 他著変なく, 肺炎像は認めなかった。

9. 骨䯣：組織学的に著変なし。

10. 上皮小体異常なし.

小括

以上の所見から病理形態学的にも生検材料の所見を参 考として原発性胆汁性肝硬变症之診断した. 直接死因は 末期に合併した敗血症の部分現象としておこった副腎の 広沉な出血, 壊死, 即ち急性副焣機能不全と考古られる. 肝硬変症の末期沈ける合併症として敗血症が見られる ことは剖検上時折経験することである. 感染門戸は本例 の場合, 結腸, 或は食道静脈瘤破糘部の炎症性病害が考 えられるが確証はない，病的骨折を巷起して稍々，著明 な骨軟化症はカルシウムの吸収及びビタミンDの吸収不 全によるるのと理解される。

\section{考按}

原発性胆汁性肝硬变症は, 欧米では, 全肝硬変の約 9 \%を占めているが，本邦では比較的稀な疾患とされ，市 田の第61回日本消化器病学会特别講演でも全国で43例と 報告されている．臨床的には成人女子に好発すると言わ れ，男女比は，市田によれば5：38で88\%が女性に発生 する (Sherlock は90\%が女性と報告している).又，初発 年柃に関しては, 市田は40歳以後の発症が $80 \%$ と述へて 扣り，内外の文献もこれに近い，初発症状としては，挜 洋感で始まるものが最多で, 市田も43例中16例（37.2

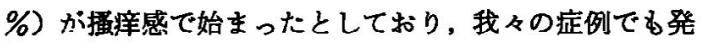
黄前約 7 カ月間は掻接感のみが先行した。一方, 生存期 間からみると，PBC の患者は 4 年から 6 年のものが多 く, 我々の例す6 年10カ月であった。

PBC に於ける肝機能生化学検査の推移をみると, $\mathrm{Al}$-ph 值は，発病より 5 年位迄は 40 K.A.U. 以上の高值 を示し，以後は下降する症例が多く, 我々の症例も同様 の傾向で，発病初期には 100 K.A.U. 前後と著明に高か ったが，末期には 500 800 国際単位（25 40 K.A.U. に相当）と可成下降した。一方，総ビリルビン值は，発 病当初は低く，4年目位から上昇して $10 \mathrm{mg} / \mathrm{d} l$ 以上とな る例が多かったが，我々の症例です 発病初期は $3 \mathrm{mg} / \mathrm{dl}$ 前後と低かったが，末期では $15 \mathrm{mg} / \mathrm{d} l$ 以上に固定した。 
更に, GOT, GPTに関しては, 末期を除いて50 150 単 位と比較的低值を持続するものが多く，我々の症例む終 始 300 単位以下の軽度上昇にとどまった. 又, 総コレス テロール值の変動をみると, 病初期には高く, 発病後 2 $\sim 3$ 年で $400 \mathrm{mg} / \mathrm{d} l$ 以上之最高值に達し, 肝硬变期に入 る $4 \sim 6$ 年以後には下降し初め，末期には軽度上昇にと どまる例が多いが，我々の症例す発病後約 1 年目に 622 $\mathrm{mg} / \mathrm{d} l$ と最高值に達したが，肝便変期に入った 6 年目に は $250 \mathrm{mg} / \mathrm{d} l$ 以下の正常値となった。

本症の病理組織学的所見に関しては，Rubin 等 ${ }^{6)}$ Williams $^{11)}$ Baggenstoss 等 ${ }^{(2)}$ K負らところが多く，病変の初 発部位 $か 440 \sim 80 \mu$ 径を持つ 中等大の 小葉間胆管にあ り，その非可逆的破罗性病变と周囲に拈けるリンパ球， 形質細胞, 組織球の浸潤を伴 5 肉芽性反応が初期病変の 中核をなすすのである事が明らかにされている。本例の 生検材料に和ける所見は，形質細胞の出現が極めて少な かったとはいえ，PBC に全く一致する所見と言ってょ W.

本症の pathogenesis に関して近年脚光を浴びてきた 自己免疫的機序の 役割については, Mackay $(1958)^{13)}$ Hamilton (1959) ${ }^{10)}$ 等によって次第に解明されてきた。 Paronetto $^{15)}$ 等は免疫蛍光法により形質細胞型の basophilic mesenchymal cells にIgM を証明し, 又, Feizi ${ }^{16)}$ は本症に括いて IgM が81\%に上昇していたと述べてお り, 我々の症例です IgMは $320 \mathrm{mg} / \mathrm{d} l$ と増加していた. 一方, 本症の免疫学的診断価值として高く評価されてい る抗ミトュンドリフ抗体の陽性率に関しては, 欧米では Doniach $^{17)}$ 等が41例中40例 (98\%) に陽性であったと述 べており，一方，本邦では市田 ${ }^{18)}$ の集計報告によると， 組織学的にPBC々訩断された18例中15例 $(83.3 \%)$ に陽 性であったとしており，我々の症例む抗胃壁細胞抗体で 256倍，抗尿細管上皮細胞抗体で 128倍と共に陽性を示 した.

PBCにおける自己免疫学的機序の関与の詳細なメカ二 ズムは現在尚不明であるが，少なくとすウイルスによる ものであれ，薬物によるものであれ，それが持続的な傷 害を組織に与え,これに関連して生じた異種蛋白が自己 免疫反応を惹起する引金となり得るであろら事は充分考 えられる。

我々の症例には薬物によると考光られる確証はなく， 生検材料より細胆管炎型のウイルス肝炎ではなかろらか と推定している.尚本例の場合，一応注目すべきは妊娠 を契機として発症していると考点られる点である。しか
17 巻 3 号 (1976)

し, 既往妊娠に黄疸発現の既往なく强㾟感は帝王切開分 婏後も軽快せず, 䄪 1 力月後に黄㾝が発症, 且つ進行性 であり，血清ビリルビン値の值等からむ妊娠に伴ら肝内 性閉塞性黄㾞は否定してよからう。

\section{おわりに}

以上, 我々の症例は黄疾に先行する搔症て始まり, 旰 腫大をきたし，生化学的検查ではアルカリフォスファタ 一セ値, 総コレステロール值が著增し, 肝外胆管の閉塞 はなく, 危疫学的にはIgMの増加と抗ミトコンドリア抗 体が陽性であり，生検並びに剖検所見からも確認され， 長期間経過を観察し得た典型的なP.B.C.と思われたので 若干の考察を加克てここに報告した。

尚, 本文の要旨は第 251 回, 内科学会関東地方会にお いて発表した。稿を終わるにあたり，病初期の諸資料を 提供して下さった整友病院内科の諸先生方並びに抗ミト コンドリフ抗体の检索を行なって下さった千集大学第 1 内科本村八恵子先生他諸先生に深謝致します。

\section{文 献}

1) Thannhauser, S.J. \& Magendantz, H.: The different clinical groups of xanthomatous disease; a clinical physiological study of 22 cases. Ann. Int. Med., 11: 1662, 1938.

2) Watson, C.J. \& Hoffbauer, F.W.: Cirrhosis. Relation to infectious hepatitis with particular reference to cholangiolitic type. Tr. A. Am. Physicians, 59: 66, 1946.

3) Watson, C.J. \& Hoffbauer, F.W.: The problem of prolonged hepatitis with particular reference to the cholangiolitis type and to the development of cholangiolitic cirrhosis of the liver. Ann. Int. Med., 25: 195, 1946.

4) MacMahon, H.E.: Biliary cirrhosis. Differential features of the five types. Lab. Invest., 4: 243, 1955.

5) Sherlock, S.: Primary biliary cirrhosis (chronic intrahepatic obstructive jaundice). Gastroenterology, 37: 574, 1959.

6) Rubin, E., Schaffner, F. \& Popper, H.: Primary biliary cirrhosis. Chronic non-suppurative destructive cholangitis. Am. J. Path., 46: 387, 196.5.

7) Hanot, V.: Etude sur une forme de cirrhose bypertrophique du foie. Thèse de Paris, 465: 
$155,1875$.

8) Kiener, P.L.: Sur un cas de maladie de Hanot ou cirrhose hypertrophique du foie avec ictère chronique. Semaine méd., 13: 345, 1893.

9) Ahrens, E.H., Jr. \& Kunkel, H.G.: The relationship between serum lipids and skin xanthomata in 18 patients with primary biliary chirrhosis. J. Clin. Invest., 28: 1565, 1949.

10) Ahrens, E.H., Jr., et al.: Primary biliary cirrhosis. Medicine, 29: 299, 1950.

11) Williams, G.E.G.: Pericholangiolitic biliary cirrhosis. J. Path. Bact., 89: 23, 1965.

12) Baggenstoss, A.H., et al.: The pathology of primary biliary cirrhosis with emphasis on histogenesis. Amm. J. Clin. Path., 42: 259, 1964.
13) Mackay, I.R.: Primary biliary cirrhosis showing a high titer of autoantibody. New Eng. J. Med., 258: 185, 1958.

14) Mamilton, J.D.: Pathology of primary biliary cirrhosis. Lab. Invest., 8: 701, 1959.

15) Paronetto, F., et al.: Immunocytochemical and serologic observations in primary biliary cirrhosis. New Eng. J. Med., 271: 1123, 1964.

16) Feizi, T.: Immunoglobulins in chronic liver disease. Gut, 9: 193, 1968.

17) Doniach, D., et al.: Tissue antibodies in primary biliary cirrhosis, active chronic (lupoid) hepatitis, cryptogenic cirrhosis and other liver diseases and their clinical implications. Clin. exp. Immunol., 1: 237, 1966.

18）市田文弘：原発性胆汁性肝硬変症. 第61回日本 消化器病学会特別講演, 1975年 3 月.

\title{
A Case of Primary Biliary Cirrhosis Followed up for More Than 7 Years
}

\author{
Tarao Kazuo, Funayama Michitoshi, Sugimasa Tatsuo, Endo Osamu, \\ Toda Yusuke, Matsuzaki Makoto, Nakamura Nobuhiko and \\ Fukushrma Kokichi* \\ Nagaoka Sadao**
}

The patient was a 42-year-old woman, whose earliest symptom was generalized pruritus, and was admitted to the Keiyu Hospital in December in 1967. Liver function tests at that time reflect cholestasis with markedly elevated alkaline phosphatase (max. 115 K.A.U.) and cholesterol levels (max. $622 \mathrm{mg}$ per $\mathrm{d} l$.), whereas serum albumin levels remained normal.

Then she admitted to our hospital on the 4th of September in 1973, complaining of severe pruritus and jaundice. After admission, the pathologic fractures of the right 9th rib occurred. In endoscopic pancreatico-cholangiography, no obstruction in extrahepatic bile ducts was found. She died of acute adrenal failure on the 21st of March in 1974. In autopsy, the liver was $1,440 \mathrm{~g}$ and histological diagnosis was primary biliary cirrhosis.

* The 1st Dept. of Medicine, Yokohama City University

** The 1st Dept. of Pathology, Yokohama City University 